\title{
Assessing the Hazard of Picloram to Cutthroat Trout
}

\author{
D.F. WOODWARD
}

\begin{abstract}
Water concentrations of picloram, comparable with those reported from field investigations, were used to simulate field exposures of cutthroat trout (Salmo clarki) to the herbicide. Picloram increased fry mortality in concentrations greater than $1,300 \mu \mathrm{g} / \mathrm{l}$ and reduced fry growth in concentrations above 610 $\mu \mathrm{g} / \mathrm{l}$. The chemical had no adverse effect on fry in concentrations below $290 \mu \mathrm{g} / \mathrm{l}$. However, if persistent rainfall were to occur, resulting in continuous loss of picloram in runnoff, the maximum allowable concentration might be much lower than $290 \mu \mathrm{g} / \mathrm{l}$.
\end{abstract}

For over 25 years herbicides have provided an effective method for improving rangeland by controlling brush and weeds (Scifres 1977). Recent public concern about the use and management of natural resources has intensified the need to determine the fate of these herbicides in the environment. New technology in residue research has made it possible to detect and trace small quantities of herbicides within the rangeland ecosystem. However, assessment of the biological importance of low herbicide residues in the environment is needed so that hazards to nontarget species can be reduced, and recommendations can be made for the safe use of herbicides in range management

Picloram (4-amino-3,5,6-trichloropicolinic acid) is one of the more effective herbicides used in controlling noxious weeds in the intermountain area (Alley et al. 1977). It is normally applied at a rate of 1.1 to $2.2 \mathrm{~kg} / \mathrm{ha}$. However, picloram is persistent in soil and tends to move away from the site of application. In field studies in Utah, picloram was consistently detected in runoff water collected $100 \mathrm{~m}$ below treatment plots (Evans and Duseja 1973). Contamination of runoff water with picloram was associated with periods of natural precipitation and continued for 50 days after application. In a Wyoming field study, Evans and Duseja (1973) measured maximum concentrations of picloram in runoff water with rainfall of $4 \mathrm{~cm} 7$ days after application. The concentrations were 2.7 and $1.8 \mathrm{mg} / \mathrm{l}$ at distances of 5 and 10 meters, respectively, from the treatment site. Similar field studies in Texas showed that plant "washoff" "was the main source of picloram contamination in runoff water (Bovey et al. 1974). The contamination of the water was greatest ( 400 to $800 \mu \mathrm{g} / \mathrm{l}$ ) when rain fell immediately after application and was low $(<5 \mu \mathrm{g} / \mathrm{l})$ when rainfall occurred 30 days or more after application. Davis and Ingebo (1973) reported residues of picloram in a stream after the application of $10.5 \mathrm{~kg} / \mathrm{ha}$ to an adjacent chaparral watershed in Arizona. Concentrations in the stream were highest during the first 3 months after application and were associated with periods of

\footnotetext{
The author is a fishery research biologist, U.S. Fish and Wildlife Service, Field Research Laboratory, Jackson, Wyoming 83001

Manuscript received May 15, 1978.
}

rainfall. Stream residues of picloram decreased from a high of $370 \mu \mathrm{g} / \mathrm{l}, 7$ days after application, to $14 \mu \mathrm{g} / 1,38$ days after application; 72 days after application, however, the concentration rose to $350 \mu \mathrm{g} / \mathrm{l}$ after a $10-\mathrm{cm}$ rain.

The purpose of the present study was to determine the biological significance of picloram residues in natural waters to cutthroat trout (Salmo clarki), a species characteristic of the intermountain area. Under the controlled conditions of a laboratory environment, I simulated the exposure concentrations reported from field investigations.

\section{Materials and Methods}

The cutthroat trout was selected for this study because it is native to the intermountain area and supports an important sport fishery in upper rangeland streams. Eyed eggs were obtained from the Jackson (Wyoming) National Fish Hatchery, and testing was begun 3 days after hatching. The early life stages are present in upper watersheds in June and July, the period when herbicides are normally applied.

Technical grade picloram ( $90 \%$ active ingredient) was obtained from Dow Chemical Co. and stock solutions were prepared in acetone on each day of exposure. Exposure was made in a proportional llow-through diluter described by Mount and Brungs (1967). The diluter contained six test aquaria, each with a water volume of 40 liters. Spring water (temperature, $9.5^{\circ} \mathrm{C} ; \mathrm{pH}, 7.4$; alkalinity, $206 \mathrm{mg} / \mathrm{l}$ as $\left(\mathrm{CaCo}_{3}\right)$ was delivered to each aquarium at a rate of $200 \mathrm{ml} / \mathrm{min}$.

Laboratory exposures were based on field studies of the occurrence of picloram in natural waters following field application, as reported by Bovey et al. (1974), Davis and Ingebo (1973), and Evans and Duseja (1973). These studies indicated that the potential for picloram contamination of surtace waters was greatest during the first 30 days after application, following periods of rainfall. The exposures were designed to simulate downstream dilution of picloram after one or more rains. I used five testing regimens (A through $E$ ) representing downstream dilution, with a $50 \%$ difference in concentration between each regimen (Table 1), and a control (not shown; control fish reccived only the acetone solvent at a rate equivalent to that in the highest picloram concentration). Each regimen was tested against the same fish four times to simulate picloram in runoff water after four rainstorms. These exposure periods began on days $1,8,15$, and 22 , when picloram was metered into each exposure concentration at the predetermined rate shown in Table 1. Metering was terminated 48 hours later (on days $3,10,17$, and 24), and picloram was gradually diluted out of the system. Metering the chemical in this manner allowed for gradual buildup and recession of picloram in the test aquaria, similar to what could be expected under natural conditions of increasing and decreasing runoff during and after a rainfall. The concentrations in each successive exposure period were reduced by $50 \%$ to simulate the decreased presence of picloram in runoff water with time. Water samples were taken on days $2,3,7,9,10,14,17$, and 24 to determine actual concentrations. Analytical determinations 
Table 1. A comparison of picloram concentrations $(\mu \mathrm{g} / \mathrm{l})$ measured in test water in the laboratory and in runoff and stream water from field investigations.

\begin{tabular}{|c|c|c|c|c|c|c|c|}
\hline \multirow{2}{*}{$\begin{array}{c}\text { Days after initiation } \\
\text { of test or field } \\
\text { application }\end{array}$} & \multicolumn{5}{|c|}{ Laboratory testing regimen } & \multicolumn{2}{|c|}{ Field investigation } \\
\hline & A & $\mathrm{B}$ & C & $\mathrm{D}$ & $\mathrm{E}$ & Runoff & Stream" \\
\hline 1 & $-b$ & - & - & - & - & $520^{c}$ & - \\
\hline 2 & 5,200 & 2,500 & 1,300 & 610 & 290 & - & - \\
\hline 3 & 7,900 & 3,200 & 1,600 & 790 & 290 & - & - \\
\hline 7 & 4 & 4 & 3 & 2 & 6 & $2,700^{d}$ & 370 \\
\hline 9 & 3,600 & 1,000 & 710 & 390 & 140 & $28^{d}$ & - \\
\hline 10 & 3,300 & 1,600 & 800 & 400 & 140 & - & 160 \\
\hline 11 & - & - & - & - & - & $15^{c}$ & - \\
\hline 13 & - & - & - & - & - & $180^{\circ}$ & - \\
\hline 14 & 0 & 1 & 0 & 0 & 0 & - & 120 \\
\hline 17 & 1,800 & 850 & 350 & 190 & 87 & - & - \\
\hline 24 & 770 & 410 & 240 & 76 & 48 & - & - \\
\hline 25 & - & - & - & - & - & - & 31 \\
\hline
\end{tabular}

\footnotetext{
"Reported by Davis and ingebo (197.3)

"Notl determined

Reported by Bovey et al. (1974)

"Reported by Evans and Duseja (197.3)
}

for picloram were a modification of the procedure used by Bjerke et al. (1967).

On the day of hatching, 50 cutthroat trout alevins (sac fry) were placed in each aquarium. Three days later weak or dead alevins were replaced, and exposure was initiated. Although the exposure was terminated on day 24 , the test was continued until day 60 to determine latent effects on growth and survival. Alevin survival, yolk absorption time, fry survival, and growth to 60 days (63 days posthatch) were determined as described by Woodward (1976). Survival of alevins and fry was compared by a binomial chi-square test for comparison of proportions, and lengths and weights of fry at 60 days were analyzed by analysis of variance and a multiple means comparison test (least significant difference) to determine significant differences between treatments (Snedecor 1965).

\section{Results and Discussion}

Concentrations of picloram residues in testing regimen $\mathrm{A}$ were higher than those reported from field investigations, but concentrations in testing regimens $B$ through $E$ were similar in intensity and duration to those reported from field studies (Table 1). The exposures in the one field study in which stream residues of picloram were reported (Davis and Ingebo 1973) most closely resemble the exposure pattern observed with testing regimen $D$ and $E$. Although the exposure regimens were not designed to reproduce specific field exposures, they did simulate the characteristic trend of periodic stream contamination after rains and decreased concentration with time.

The biological significance of picloram to cutthroat trout can be evaluated from results of the different exposure regimens

Table 2. Effects of picloram on growth and development of cutthroat trout at $9.5^{\circ} \mathrm{C}$ under conditions simulating field exposure.

\begin{tabular}{ccccccc}
\hline $\begin{array}{c}\text { Exposure } \\
\text { regimen }^{\prime \prime}\end{array}$ & $\begin{array}{c}\text { Yolk } \\
\text { absorption } \\
\text { (days) }\end{array}$ & $\begin{array}{c}\text { Alevin } \\
\text { survival }^{\prime}\end{array}$ & $\begin{array}{c}\text { Fry } \\
(\%)\end{array}$ & $\begin{array}{c}\text { Survival } \\
(\%)\end{array}$ & $\begin{array}{c}\text { Weight } \\
(\mathrm{mg})\end{array}$ & $\begin{array}{c}\text { Length } \\
(\mathrm{mm})\end{array}$ \\
\hline $\mathrm{A}$ & - & 0 & - & - & - \\
$\mathrm{B}$ & 27 & 70 & 2 & 40 & 22 \\
$\mathrm{C}$ & 25 & 94 & 38 & 210 & 29 \\
$\mathrm{D}$ & 25 & 96 & 92 & 320 & 34 \\
$\mathrm{E}$ & 24 & 98 & 94 & 430 & 37 \\
Control & 24 & 98 & 84 & 430 & 37 \\
\hline
\end{tabular}

"Sec Table 1.

"Calculated from hatching date to date when $50 \%$ of alevins had absorbed yolk sacs.

"Italicized values are significantly different from controls $1 P \leq 0.05$ )
(Table 2). Exposure to regimen A resulted in 100\% mortality of cutthroat trout alevins during the first 2 weeks. Alevins developing in exposure regimen B took 3 days longer to absorb yolk material and had significantly fewer survivors $(P \leq 0.05)$ than the control. Yolk absorption time and survival rate were similar in alevins exposed to regimens $\mathrm{C}$ through $\mathrm{E}$ and the control. Even though the final exposure was terminated at 24 days, most of the mortality in regimens $B$ and $C$ occurred after the 30th day of the test, during the fry stage of development. Compared with the controls, fry survival in regimens $\mathrm{B}$ and $\mathrm{C}$ was significantly $(P \leq 0.05)$ reduced to 2 and $38 \%$, respectively. Fry survival in regimens $D$ and $E$ was similiar to that in the controls, but fry growth to 60 days was significantly less $(P \leq 0.05)$ in regimen D than in fry developing in regimen $E$ and the controls. No significant differences $(P>0.05)$ were observed in development, survival, and growth of alevins and fry between the lowest exposure (regimen E) and the control.

In previous testing reported by Woodward (1976), acute toxicity (96-h LC50, concentration lethal to $50 \%$ of the organisms in 96 hours) of picloram to cutthroat trout and lake trout (Salvelinus namaycush) ranged from 2,000 to $8,600 \mu \mathrm{g} / \mathrm{l}$. Chronic testing for 60 days with lake trout reduced survival and growth at $35 \mu \mathrm{g} / \mathrm{l}$ picloram. Although lake trout were not more sensitive to picloram than cutthroat trout under acute conditions, the continuous exposure apparently adversely affected lake trout at concentrations much lower than those in the simulated field exposures used in this study with cutthroat trout. In the present study, the lowest concentration of picloram having an adverse effect on cutthroat trout was that in exposure $\mathrm{D}$; the concentration ranged from a maximum of $790 \mu \mathrm{g} / \mathrm{l}$ during the first exposure period to $76 \mu \mathrm{g} / \mathrm{l}$ during the fourth exposure period. These concentrations of picloram showing effects on fish are considerably lower than those reported to produce harmful effects after short-term exposure (Juntunen and Norris 1972; Kenaga 1969; Woodward 1976). Maximum exposure concentrations not affecting survival and growth of cutthroat trout (regimen E) ranged from 290 to $48 \mu \mathrm{g} / \mathrm{l}$.

In formulating recommendations for the use of picloram on rangeland, managers should consider the persistence and mobility of picloram in soil and water and the resulting hazard to aquatic habitats. Picloram should be applied on rangelands in a manner such that residues in adjacent streams and lakes do not exceed $290 \mu \mathrm{g} / \mathrm{l}$ following the first major rainfall after appli- 
cation. However, if persistent rainfall were to occur, this maximum allowable concentration would probably be much lower. Since rainfall is not predictable, an adequate buffer zone should be maintained between natural waters and the application area, and picloram should not be applied on stream and lake slopes.

\section{Literature Cited}

Alley, H.P., A.F. Gale, and N.E. Humburg. 1977. Wyoming weed control guide. 1977. Univ. Wyoming Agr. Ext. Serv. Bull. 422 R 42 p.

Bjerke, E.L., A.H. Kutschinski, and J.C. Ramsey. 1967. Determination of residues of 4-amino-3,5, 6-tricholoropicolinic acid in cereal grains by gas chromatography. J. Agr. Food Chem. 15:469-473.

Bovey, R.W., E. Burnett, C. Richardson, M.G. Merkle, J.R. Baur, and W.G. Knisel. 1974. Occurrence of 2,4,5-T and picloram in surface runoff water in the black lands of Texas. J. Environ. Qual. 3:61-64.
Davis, E.A., and P.A. Ingebo. 1973. Picloram movement from the chaparral watershed. Water Resour. Res. 9:1304-1313.

Evans, J.O., and D.R. Duseja. 1973. Herbicide contamination of surface runoff waters. U.S. Environ. Prot. Agency, Washington, D.C. Environ. Prot. Tech. Ser. EPA-R2-73-266 99 p.

Juntunen, E.T., and L.A. Norris. 1972. Field application of herbicidesavoiding danger to fish. Oregon State Univ. Agr. Exp. Sta. Spec. Rep. 354. 26p.

Kenaga, E.E. 1969. Tordon herbicides-evaluation of safety to fish and birds. Down to Earth. 25:5-9.

Mount, D.I., and W.A. Brungs. 1967. A simplified dosing apparatus for fish toxicological studies. Water Res. 1:21-29.

Scifres, C.J. 1977. Herbicides and the range ecosystem: Residues, research, and the role of rangemen. J. Range Manage. 30:86-91.

Snedecor, G.W. 1965. Statistical Methods. Iowa State Univ. Press, Ames, lowa, $534 \mathrm{p}$.

Woodward, D.F. 1976. Toxicity of the herbicides dinoseb and picloram to cutthroat (Salmo clarki) and lake trout (Salvelinus namaycush). J. Fish. Res. Board Can. 33:1671-1676. 